\title{
FIRST LINE THERAPY OF METASTATIC UROTHELIAL BLADDER CANCER
}

\author{
LORENA STAMIČAR ${ }^{1}$ and MARIJA GAMULIN ${ }^{1,2}$ \\ ${ }^{1}$ University of Zagreb School of Medicine, Zagreb, Croatia; \\ ${ }^{2}$ Department of Oncology, University Hospital Center Zagreb, Zagreb, Croatia
}

\begin{abstract}
Summary
This manuscript reviewes recent knowledge regarding first line therapy of metastatic urothelial bladder cancer. Bladder cancer is on the $10^{\text {th }}$ place in the world by its incidence, and more prevalent in men. Patients with metastatic urothelial cancer should be classified into one of the two groups: cisplatin-eligible and cisplatin-ineligible. Cisplatin-eligible can be treated with cisplatin based regimens and have better outcome. Cisplatin-ineligible patients (40-50\%) are cisplatin-ineligible patients are primarily those with creatinine clirence les than $50 \mathrm{ml} / \mathrm{min}$, the ones with certain comorbities and/or poor ECOG performance status, and, as an alternative, can be treated with carboplatin which is less effective. After the diagnosis of metastatic bladder cancer has been confirmed, it is necessary to choose one of the cisplatin based chemotherapy regimens. However, one should have in mind that cisplatin can cause certain side effects such as nephrotoxic, neurotoxic and ototoxic effects.
\end{abstract}

A minority of patients are not eligible for any platinum-containing chemotherapy regimen.

Besides chemotherapy regimens, checkpoint inhibitors (CPIs)-PD-1 and PD-L1 inhibitors play an important role in first-line therapy of metastatic urothelial cancer. NCCN guidelines have included avelumab, pembrolizumab and atezolizumab in a first-line systemic therapy. Recently, Javelin Bladder 100 study has confirmed a positive impact of avelumab as a maitenance therapy in cisplatin-eligible and cisplatin-ineligible patients, which is why the combination of chemotherapy and avelumab is nowadays deemed to be the best therapeutic option.

KEYWORDS: first line therapy, metastatic urothelial bladder cancer, maintenance immunotherapy

\section{INTRODUCTION}

Bladder cancer is on the $10^{\text {th }}$ place in the world(1). It is more frequent among men, which has been shown in Croatian National Cancer Registry for 2017 as well, being $5^{\text {th }}$ most common cancer site with incidence of $5 \%$, while the incidence among women was $2 \%(2)$. Most common patohistological type is urothelial cancer. After the diagnosis has been confirmed, it is necessary to establish whether it is non-muscle invasive disease or

Corresponding author: Marija Gamulin, University od Zagreb School of Medicine, Zagreb, Croatia, and Department of Oncology, University Hospital Center Zagreb, Kišpatićeva 12, 10000 Zagreb, Croatia.e-mail:mgamulin8@gmail.com muscle-invasive and metastatic disease on which the terapeutic choice will depend.

Patients with metastatic urothelial cancer should be classified into one of the two groups: cisplatin-eligible and cisplatin-ineligible. Cisplatin-eligible can be treated with cisplatin based regimens and have better outcomes(3). Cisplatin-ineligible patients are primarily distinguished based on cretinine clearence the ones with certain comorbities and/or poor ECOG performance status, and, as an alternative, can be treated with carboplatin which is less effective. A minority of patients is not eligible for any platinum-containing chemotherapy regimen.

Besides chemotherapy regimens, checkpoint inhibitors (CPIs)-PD-1 and PD-L1 inhibitors play 
an important role in first-line therapy of metastatic urothelial cancer. NCCN guidelines have included avelumab, pembrolizumab and atezolizumab in a first-line systemic therapy regarding the JAVELIN Bladder 100 clinical study(4). All of them are humanized monoclonal antibodies-pembrolizumab targets PD-1, while avelumab and atezolizumab target PD-L1. This type of therapy disables the inactivation of T-cells by which it prolonges an immune response in tumor and decreases its enlargement. Based on the results of the phase III clinical studies, avelumab is used as a maintenance therapy after initial chemotherapy regimens, while atezolizumab and pembrolizum$\mathrm{ab}$ as monotherapy are one of the options of cisplatin-ineligible patients $(4,5)$. Besides these CPIs, nivolumab and durvalumab have been approved as well but as second-line therapy only(5).

For bladder cancer this is actually more exemption. Some of the chemotherapy regimens and CPIs have synergistic effect, a good example being avelumab and GC (or GemCarbo), that is avelumab and ddMVAC as a first-line systemic therapy. An assumption is that chemotherapy, besides having a direct cytotoxic effect on cells, increases a release and presenting of antigens which then increases an immune response so that CPIs have a stronger effect(5). Therefore, avelumab as a maintenance therapy is effective for both cisplatin-eligible and ineligible patients.

\section{DISCUSSION}

After the diagnosis of metastatic bladder cancer has been confirmed, it is necessary to consider patient fitness to be treated with cisplatin.. However, one should have in mind that cisplatin can cause certain side effects such as nephrotoxic, neurotoxic and ototoxic effects. Besides that, the cisplatin administration requires abundant hydration of a patient which is why one should bear in mind patient's cardiovascular comorbidities(6). Hence, there is a defined criteria for patients who should not be treated with cisplatin based regimens.

Patients who do not have any of the above comorbidities are candidates for cisplatin based regimens and they form the cisplatin-eligible group of patients. Poor ECOG performance status, certain degree of kidney, cardiac, hearing or neurologic damage classifies a patient as cisplatin-ineligible.
Table 1.

Criteria that define cisplatin-ineligible patients. (Nadal, Rosa, and Joaquim Bellmunt. "Cytotoxic Chemotherapy for Advanced Bladder and Upper Tract Cancer." Bladder Cancer. Springer, Cham, 2021. 289-304.)(7)

Patients meeting at least one of the following are unfit for cisplatin-based chemotherapy

WHO or ECOG performance status 2, or Karnofsky performance status of $60-70 \%$

Creatinine clearance (calculated or measured) less than $60 \mathrm{ml} / \mathrm{min} / 1.73 \mathrm{~m}^{2}$.

CTCAE grade 2 or above audiometric hearing loss.

CTCAE grade 2 or above peripheral neuropathy.

NYHA class III heart failure.

\section{CISPLATIN-ELIGIBLE PATIENTS}

\section{CISPLATIN BASED REGIMENS}

According to previous guidelines, first-line therapy of metastatic urothelial cancer for this group of patients has been GC (gemcitabine and cisplatin) or MVAC (methotrexate, vinblastine, doxorubicin and cisplatin) regimen. Even though both of the regimens had similar outcomes comparing overall survival, 4-week MVAC regimen caused numerous side effects which is why it is no longer used(8). Instead, dose-dense MVAC regimen has been approved and it implies 2-week cycles of treatment. The use of ddMVAC chemotherapy regimen has decreased toxicity profile when compared to previous MVAC protocol, so the regimens most commoly used are GC and ddMVAC.

A large progression in treating these patients has started with molecular testing of tumor cells and introducing immunotherapy, alongside with genomic tumor profiling. Studies have shown that certain combinations of checkpoint inhibitors and chemotherapy show promising results.

According to the latest NCCN guidelines, there are two first-line systemic therapy regimens for this group of patients. First option implies GC regimen followed by avelumab maintenance therapy. Second option is use of ddMVAC regimen with growth factor support followed by avelumab maintenance therapy.

\section{CISPLATIN-INELIGIBLE PATIENTS}

Analogously to cisplatin-eligible patients, first-line therapy for metastatic urothelial cancer for this group have been chemotherapy regimens only. Substituting cisplatin for carboplatin, two ef- 
fective regimens were discovered- MCAVI (methotrexate, carboplatin and vinblastine) and GemCarbo (gemcitabine and carboplatin). However, the results of EORTC 30986 study have compared the results of the regimens above and it has been noticed that MCAVI regimen has more toxic side effects which is why only GemCarbo was in further use(9).

First-line therapy of metastatic urothelial cancer has significantly changed for this group as well. One option is the use of previously mentioned GemCarbo regimen followed by avelumab maintenance therapy.

Second option implies atezolizumab or pembrolizumab treatment as monotherapy. After numerous clinical studies a conclusion has been made that atezolizumab is effective in those patients with PD-L1 $\geq 5 \%$ and in those who are not eligible for any platinum-containing chemotherapy. The same applies for pembrolizumab, but the expression of PD-L1 should be $\geq 10 \%$.

The effect of taxanes on patients with metastatic urothelial cancer has been observed in randomised clinical studies. For instance, in one of the studies the comparison was made between GC regimen alone and GC regimen with addition of paclitaxel. Even though the regimen which included paclitaxel led to a bit of an improvement in overall survival, the conclusion was that the benefit from this regimen is small in comparison to the risk of bad side effects(10). However, treating patients who are not eligible for any platinumcontaining chemotherapy is challenging, so in these patients as first-line systemic therapy, a combination of gemcitabine and paclitaxel(11) or gemcitabine alone can be observed(12). Another option for these patients is combination of ifosfamide, doxorubicin and gemcitabine(13).

\section{Avelumab, atezolizumab and pembrolizumab as first-line systemic therapy-important clinical studies}

Javelin Bladder 100 study is phase III of clinical trial in which the effect of avelumab as a maintenance therapy has been investigated. Patients who were enrolled in the study were those with locally advanced or metastatic urothelial cancer. They were given 4-6 cycles of GC chemotherapy regimen (that is carboplatin instead of cisplatin in cisplatin-ineligible patients). Afterwards, there was a period of 4-10 weeks during which the patiens were examined to estimate their response to chemotherapy so that the patients who showed an improvement can be treated with avelumab as a maintenance therapy. Therapeutic response to the therapy included patients with stable disease, partial or complete response to the chemotherapy. Out of two groups of patiens, one recieved avelumab and best supportive care, and the other one, control group, best supportive care alone. PD-L1 status was determined in both groups so that the effect of avelumab can be estimated in both total and PD-L1 positive population. The study results have shown that the overall survival was significantly higher in the avelumab group observing total and PD-L1 positive patients. Comparison of these two groups showed that overall survival in a year for patients who recieved chemotherapy and avelumab was $71,3 \%$ with mOS (median of overall survival) 21,4 months, while OS in a group without avelumab was $58,4 \%$ with mOS 14,3 months. Between PD-L1 positive patients from both groups the difference was even higher, OS of $79,1 \%$ in a year for patients on avelumab, and $60,4 \%$ for the ones in the control group. PFS (progression-free survival) was significantly higher in the avelumab group, too(14).

KEYNOTE-045 clinical trial (phase III) has demonstrated the efficiency of pembrolizumab in second-line therapy of metastatic urothelial cancer. The conclusion of this study was that patients who had a progression of urothelial cancer after first-line chemotherapy regimen, had a longer mOS if progression was treated with pembrolizumab rather than another administration of chemotherapy (10,3 months in comparison to 7,4 months). The response was independent of PD-L1 positivity(15).

Pembrolizumab as a first-line therapy of metastatic urothelial cancer was studied in KEYNOTE-052 study (phase II). Patients who had PD$\mathrm{L} 1 \geq 10 \%$ have shown a better response to the pembrolizumab treatment. For the whole population, mOS was 11,5 months and in those with PD-L1 expression $\geq 10 \%$ it was 18,5 months(16).

KEYNOTE-361 study is a phase III clinical trial of pembrolizumab as first-line therapy. Three different modalities of treatment have been used in this study: a group treated with combination of chemotherapy and pembrolizumab, a group treat- 
(A) OS

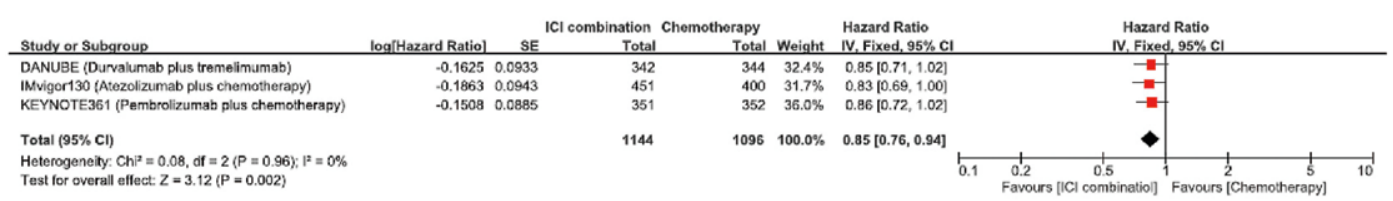

(B) OS (ICI-chemotherapy combination only)

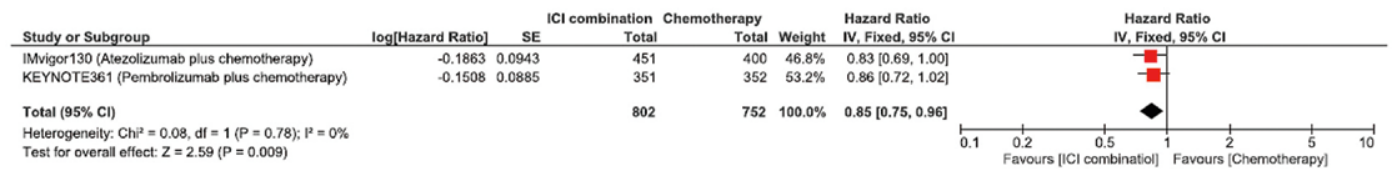

(C) PFS

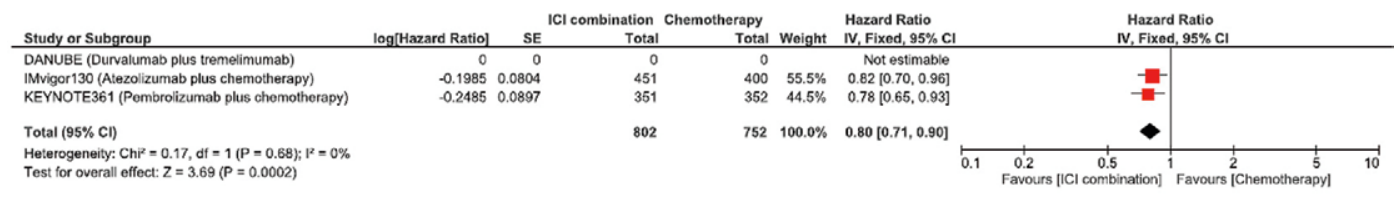

(D) ORR

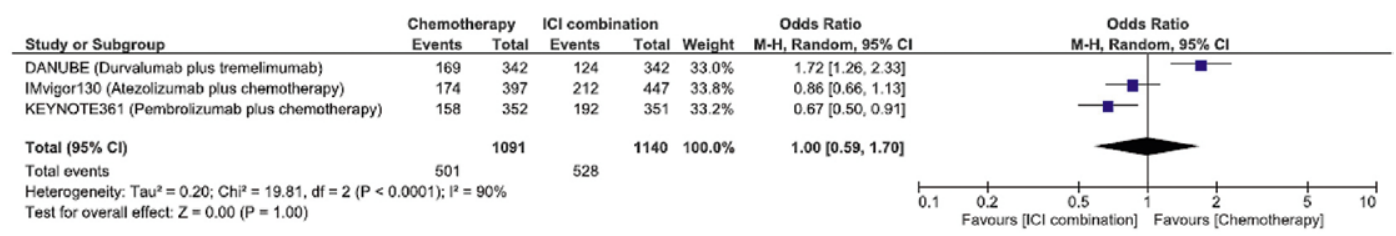

(E) ORR (ICI-chemotherapy combination only)

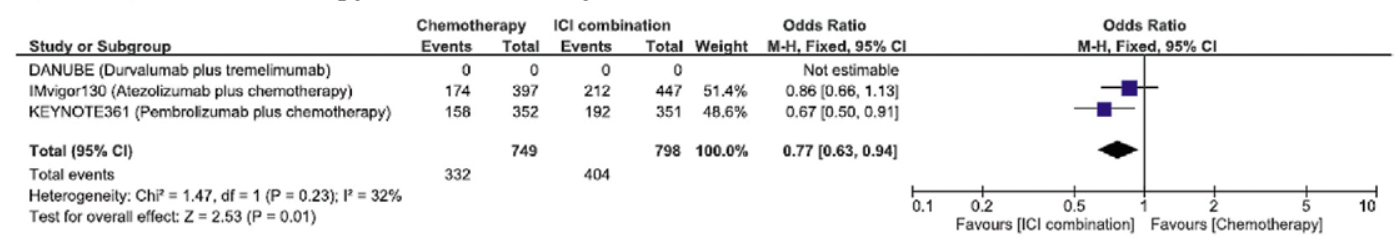

(F) CRR

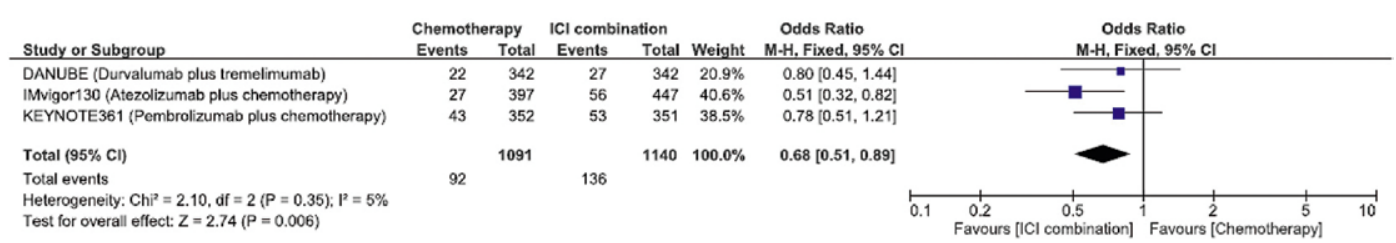

(G) CRR (ICI-chemotherapy combination only)

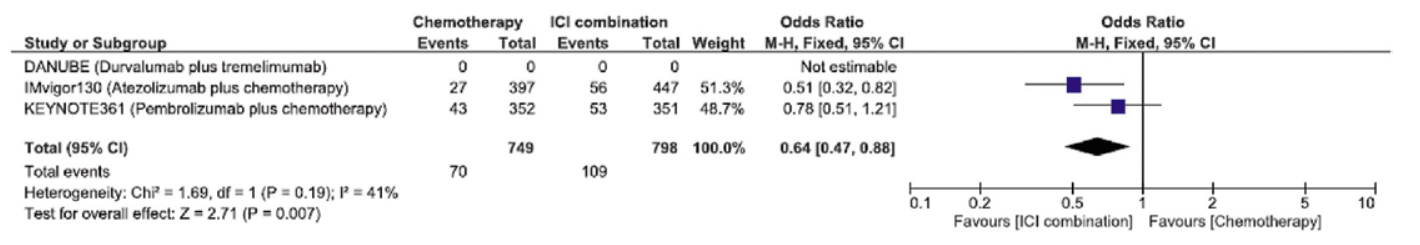

Figure 1. The comparison of a combination which includes checkpoint inhibitors with chemotherapy (5). (From: Mori K, Pradere B, Moschini M, et al. First-line immune-checkpoint inhibitor combination therapy for chemotherapy-eligible patients with metastatic urothelial carcinoma: A systematic review and meta-analysis. European Journal of Cancer 2021;151: 35-48.) 
(H) DOR

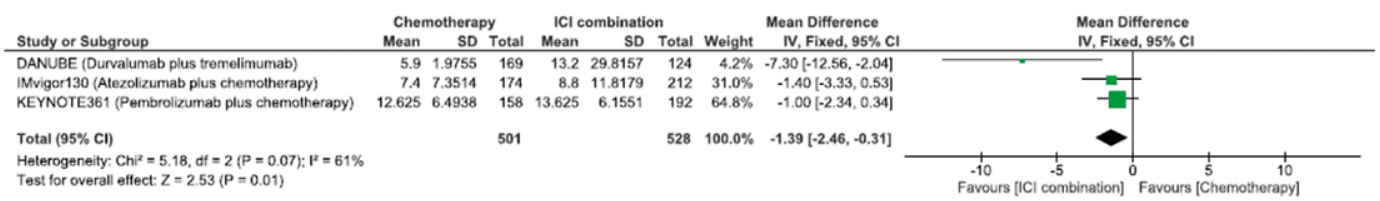

(I) DOR (ICI-chemotherapy combination only)

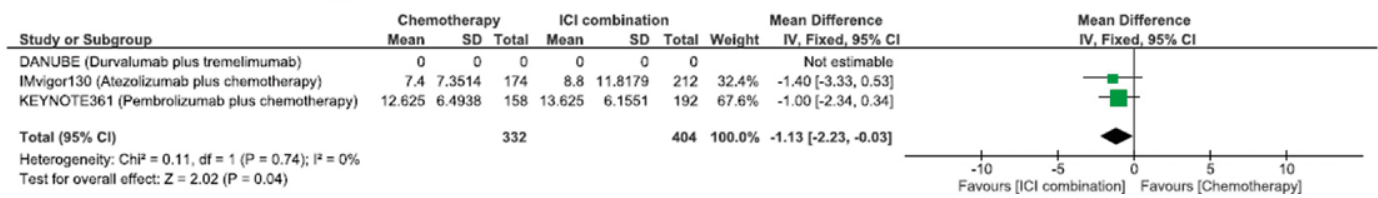

Figure 1.-continued

(A) OS

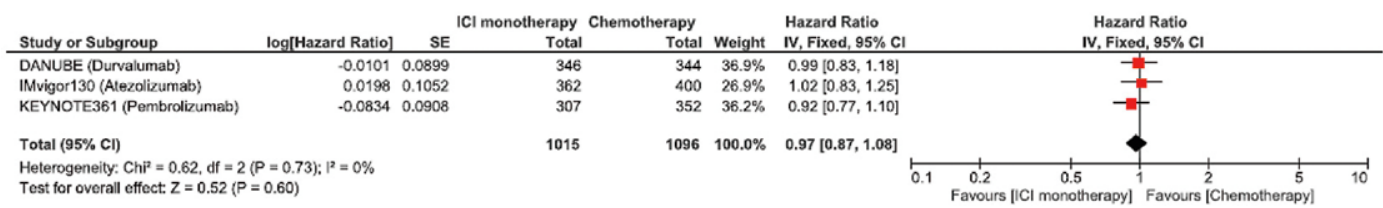

(B) ORR

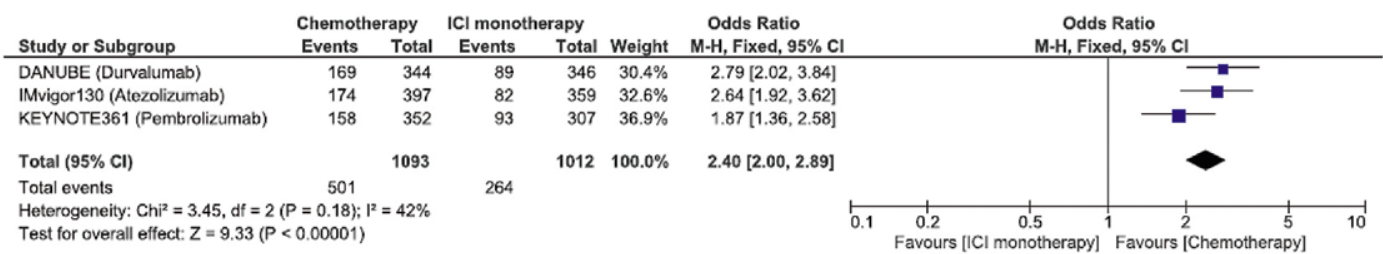

(C) $\mathrm{CRR}$

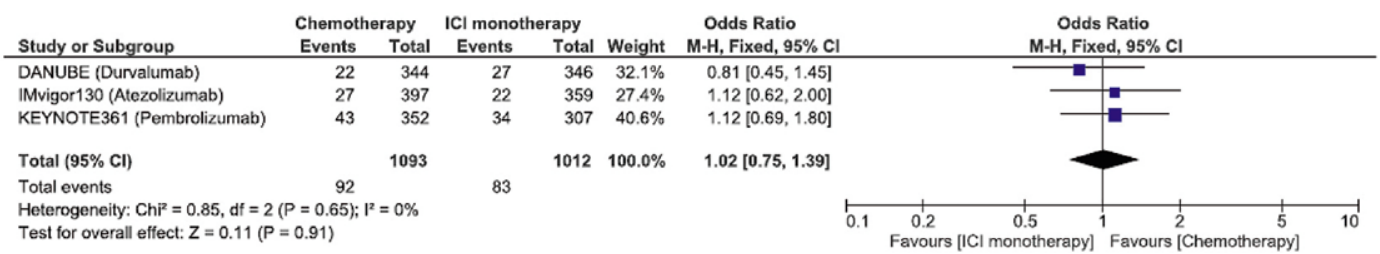

Figure 2. Checkpoint inhibitors as a monotherapy and chemotherapy(5). (From: Mori K, Pradere B, Moschini $M$, et al. First-line immune-checkpoint inhibitor combination therapy for chemotherapy-eligible patients with metastatic urothelial carcinoma: A systematic review and meta-analysis. European Journal of Cancer 2021;151: 35-48.)

ed with pembrolizumab as a monotherapy and a group treated with chemotherapy. The goal was to compare the efficiency of pembrolizumab and chemotherapy combination and chemotherapy alone. The combination of pembrolizumab and chemoterapy did not show promising results thus this combination should not be used as a treatment option(17).

Based on IMvigor210 study, atezolizumab was approved as a second-line therapy option for metastatic urothelial cancer and as first-line therapy for cisplatin-ineligible patients. This was phase 
(A) OS in high PD-L1 (ICI combination therapy versus chemotherapy)

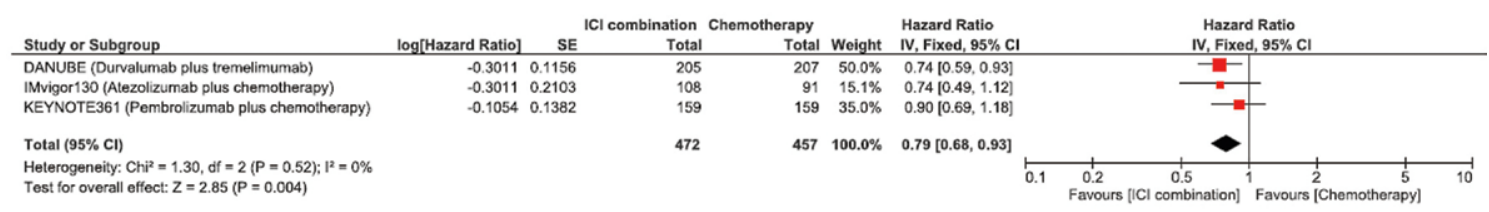

(B) OS in low PD-L1 (ICI combination therapy versus chemotherapy)

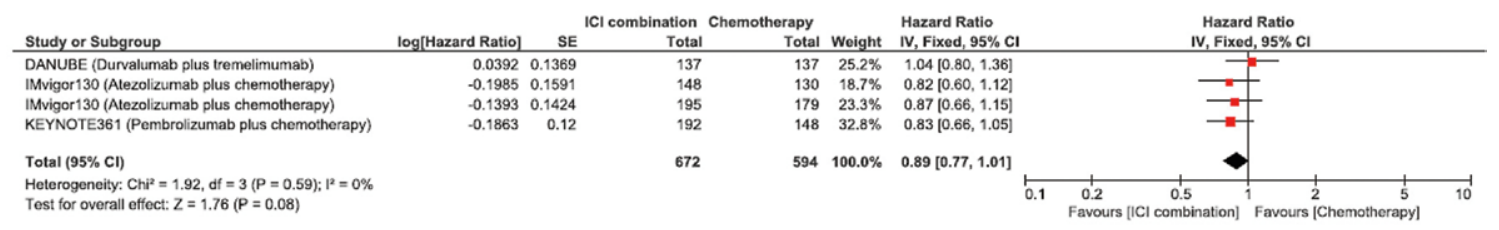

(C) PFS in high PD-L1 (ICI combination therapy versus chemotherapy)

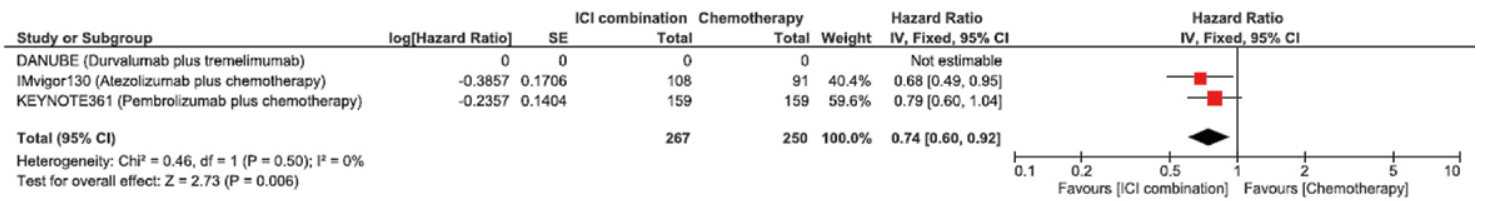

(D) PFS in low PD-L1 (ICI combination therapy versus chemotherapy)

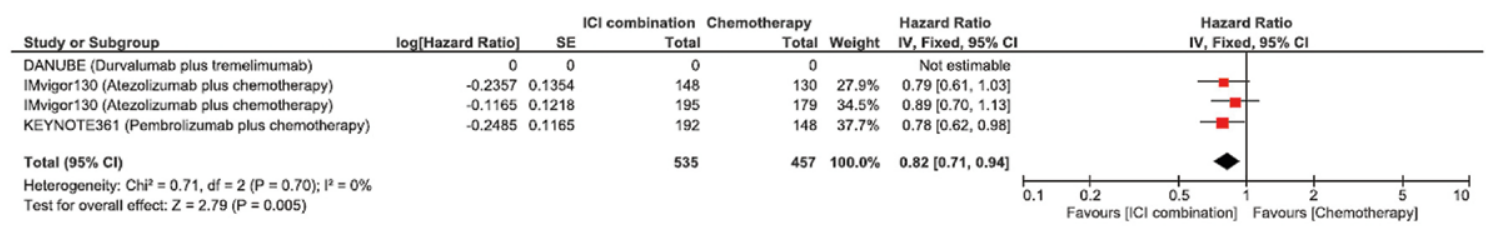

(E) OS in high PD-L1 (ICI monotherapy versus chemotherapy)

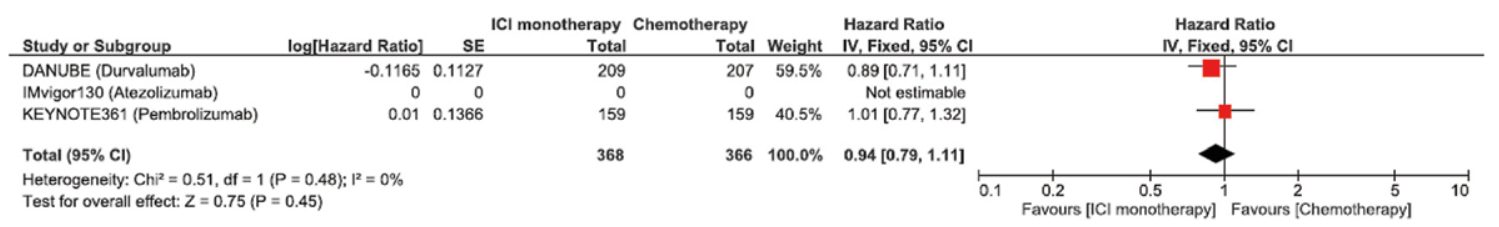

Figure 3. Therapeutic effect depending on PD-L1 status (5). (From: Mori K, Pradere B, Moschini M, et al. First-line immune-checkpoint inhibitor combination therapy for chemotherapy-eligible patients with metastatic urothelial carcinoma: A systematic review and meta-analysis. European Journal of Cancer 2021;151: 35-48.)

II clinical trial which consisted of two groups of patients (patients previously treated with chemotherapy and cisplatin-ineligible patients) and both of them were treated with atezolizumab. ORR (objective response rate) was $15 \%$ unlike patients who were treated only with chemotherapy whose ORR was $10 \%$. Patients with PD-L1 expression $\geq 5 \%$ have shown better response to atezolizumab treatmentone year OS for a whole population was $37 \%$, while for those with PD-L1 $\geq 5 \%$ it was $50 \%(18)$.
Phase III clinical trial for atezolizumab as second-line therapy was IMvigor 211. The efficacy of atezolizumab and chemotherapy has been compared. MOS for the group of patients with PDL1 $25 \%$ who recieved atezolizumab was not significantly higher than for the group which was treated with chemotherapy (vinflunine, paclitaxel or docetaxel-depending on investigator's choice). The efficacy of atezolizumab was based on DoR (duration of response)-15,9 months in comparison 
to 8,3 months in patients treated with chemotherapy(19).

IMvigor130 study has demonstrated the efficacy of atezolizumab as first-line therapy option of metastatic urothelial cancer. Similar to KEYNOTE-361 study, patients were divided into three groups: atezolizumab+chemotherapy, atezolizumab as a monotherapy and chemotherapy. This study has proved that the patients in group with atezolizumab and chemotherapy combination had longer mOS than the ones in chemotherapy group (16 in comparison to 13,4 months) as well as longer PFS (8,2 in comparison to 6,3 months)(20).

In a large meta-analysis carried out by $\mathrm{K}$. Mori et al.(5) that investigated the efficacy of CPIs have been compared in order to determine their role in first-line treatment of metastatic urothelial cancer. For some of the regimens, a favorable effect has been demonstrated very clearly, for example Javelin bladder 100 study has confirmed a positive impact of avelumab as a maitenance therapy which is why the combination of chemotherapy and avelumab is included in the guidelines. On the other hand, some of the treatment options such as durvalumab and nivolumab have been approved as a second-line therapy but their role in first-line therapy is still not certain and this is yet to be researched.

Figure 1. demonstrates the comparison of a combination which includes CPI with chemotherapy. In total, studies favorize combination with CPI in terms of OS, PFS, ORR, CRR and DoR (except for 1.D because it includes Danube study in which chemotherapy was proven to be more effective than the combination of durvalumab and tremelimumab).

Figure 2. compares CPI as a monotherapy and chemotherapy. It has been demonstrated that OS and CRR have approximately the same values, while the ORR favorizes chemotherapy.

Therapeutic effect has been studied depending on PD-L1 status, as well (Figure 3.). It has been noticed that there is a correlation between high PD-L1 expression and OS when it comes to CPI treatment. On the contrary, PFS was higher among patients treated with combination which includes CPI regardless of PD-L1 status. CPI monotherapy was not more effective than the chemotherapy when comparing OS.

In this meta-analysis, a combination which includes CPI (especially a combination of chemo- therapy and CPI) has proven to be a better option than the chemotherapy alone for patients with metastatic urothelial cancer. However, CPIs as a monotherapy are not that effective. Monotherapy with CPIs is a good alternative for patients not eligible for chemotherapy, besides they cause less side-effects than chemotherapy. The role of PD-L1 status is not completely clarified yet and it is still not certain if higher PD-L1 expression correlates with higher response to the CPIs treatment.

\section{CONCLUSION}

The use of molecular, that is genomic profiling is increasing in medicine, which refers to investigating therapeutic options of metastatic urothelial cancer as well. Currently, in purpose of implementation targeted systemic therapy, PD-1/ PD-L1 testing is most commonly used and these investigations have led to development of effective first-line therapy options for some patients(21). The ultimate goal is to explore the genes whose mutations affect therapeutic response and to personalize therapy for each patient from the beginning. For example, a study conducted by Joshi et al.(22) has proven that the higher number of DDR (DNA damage response) mutations correlates with better therapeutic response to PD-1/ PD-L1 inhibitors and higher rate of OS, while ATM deletions or mutations have negative predictive value. There is still a lot to be discovered when it comes to genomic profiling in oncology, CPIs being the begging of this large chapter.

\section{REFERENCES}

1. https://gco.iarc.fr/today/online-analysis-table?v=2020 $\&$ mode=cancer\&mode_population=continents\&popu lation $=900 \&$ populations $=900 \& \mathrm{key}=\mathrm{asr} \& \mathrm{sex}=0 \&$ cancer $=39 \&$ type $=0 \&$ statistic $=5 \&$ prevalence $=0 \&$ population group $=0$ \&ages_group $\% 5 \mathrm{~B} \% 5 \mathrm{D}=0$ \&ages_group $\% 5 \mathrm{~B} \%$ $5 \mathrm{D}=17$ \&group_cancer $=1$ \&include_nmsc $=1$ \&include_ nmsc_other=1\#collapse-by_country (accessed: October $25^{\text {th }}, 2021$ )

2. Croatian Institute for Public Health. Croatian National Cancer Registry. Cancer incidence in Croatia 2017. Biltem 42. Zagreb, 2020.

3. Bellmunt J, Ribas A, Eres N, Albanell J, Almanza C, Bermejo B, et al. Carboplatin-based versus cisplatinbased chemotherapy in the treatment of surgically incurable advanced bladder carcinoma. Cancer. 1997;80 (10):1966-72. 
4. National Comprehensive Cancer Network. NCCN Clinical Practice Guidelines in Oncology. Bladder Cancer. Version 4.2021.

5. Mori K, Pradere B, Moschini M, Mostafaei H, Laukhtina E, Schuettfort VM, et al. First-line immune-checkpoint inhibitor combination therapy for chemotherapy-eligible patients with metastatic urothelial carcinoma: A systematic review and meta-analysis. Eur J Cancer. 2021;151:35-48.

6. Jazvić, Marijana, Ružić B, Krušlin B, Šitum M, Pešutić Pisac V, Omrčen T, et al. Smjernice za dijagnosticiranje, liječenje i praćenje bolesnika s rakom mokraćnog mjehura. Liječnički vjesnik 2019;141(11-12):326-35.

7. Nadal R., Bellmunt J. (2021) Cytotoxic Chemotherapy for Advanced Bladder and Upper Tract Cancer. In: Kamat A.M., Black P.C. (eds) Bladder Cancer. Springer, Cham. https://doi.org/10.1007/978-3-030-70646-3_24

8. Sternberg CN, de Mulder PHM, Schornagel JH, Théodore C, Fossa SD, van Oosterom AT, et al. Randomized Phase III Trial of High-Dose-Intensity Methotrexate, Vinblastine, Doxorubicin, and Cisplatin (MVAC) Chemotherapy and Recombinant Human Granulocyte Colony-Stimulating Factor Versus Classic MVAC in Advanced Urothelial Tract Tumors: European Organization for Research and Treatment of Cancer Protocol No. 30924. J Clin Oncol. 2001;19 (10):2638-46.

9. De Santis M, Bellmunt J, Mead G, Kerst JM, Leahy M, Maroto P, et al. Randomized phase II/III trial assessing gemcitabine/ carboplatin and methotrexate/carboplatin/vinblastine in patients with advanced urothelial cancer "unfit" for cisplatin-based chemotherapy: phase II--results of EORTC study 30986. J Clin Oncol. 2009;27(33):5634-9.

10. Bellmunt J, von der Maase H, Mead GM, Skoneczna I, De Santis M, Daugaard G, et al. Randomized phase III study comparing paclitaxel/cisplatin/gemcitabine and gemcitabine/cisplatin in patients with locally advanced or metastatic urothelial cancer without prior systemic therapy: EORTC Intergroup Study 30987. J Clin Oncol. 2012;30(10):1107-13.

11. Calabrò F, Lorusso V, Rosati G, Manzione L, Frassineti L, Sava T, et al. Gemcitabine and paclitaxel every 2 weeks in patients with previously untreated urothelial carcinoma. Cancer. 2009;115(12):2652-9.

12. Stadler WM, Kuzel T, Roth B, Raghavan D, Dorr FA. Phase II study of single-agent gemcitabine in previously untreated patients with metastatic urothelial cancer. J Clin Oncol. 1997;15(11):3394-8.

13. Siefker-Radtke AO, Dinney CP, Shen Y, Williams DL, Kamat AM, Grossman HB, et al. A phase 2 clinical trial of sequential neoadjuvant chemotherapy with ifosfamide, doxorubicin, and gemcitabine followed by cisplatin, gemcitabine, and ifosfamide in locally ad- vanced urothelial cancer: final results. Cancer. 2013; 119(3):540-7.

14. Powles T, Park SH, Voog E, Caserta C, Valderrama BP, Gurney $\mathrm{H}$ et al. Maintenance avelumab+ best supportive care (BSC) versus BSC alone after platinum-based first-line chemotherapy in advanced urothelial carcinoma: JAVELIN Bladder 100 phase III results. J Clin Oncol 2020 38:18_suppl, LBA1-LBA1.

15. Vaughn DJ, Bellmunt J, Fradet Y, Lee JL, Fong L, Vogelzang NJ, et al. Health-Related Quality-of-Life Analysis From KEYNOTE-045: A Phase III Study of Pembrolizumab Versus Chemotherapy for Previously Treated Advanced Urothelial Cancer. J Clin Oncol. 2018;36(16):1579-87.

16. Balar AV, Castellano D, O’Donnell PH, Grivas P, Vuky J, Powles T, et al. First-line pembrolizumab in cisplatin-ineligible patients with locally advanced and unresectable or metastatic urothelial cancer (KEYNOTE052): a multicentre, single-arm, phase 2 study. Lancet Oncol. 2017;18(11):1483-1492.

17. Powles T, Csőszi T, Özgüroğlu M, Matsubara N, Géczi L, Cheng SY, et al. Pembrolizumab alone or combined with chemotherapy versus chemotherapy as first-line therapy for advanced urothelial carcinoma (KEYNOTE-361): a randomised, open-label, phase 3 trial. Lancet Oncol. 2021;22(7):931-45.

18. Necchi A, Joseph RW, Loriot Y, Hoffman-Censits J, Perez-Gracia JL, Petrylak DP, et al. Atezolizumab in platinum-treated locally advanced or metastatic urothelial carcinoma: post-progression outcomes from the phase II IMvigor210 study. Ann Oncol. 2017; 28(12):3044-50.

19. Powles T, Durán I, van der Heijden MS, Loriot $Y$, Vogelzang NJ, De Giorgi U, et al. Atezolizumab versus chemotherapy in patients with platinum-treated locally advanced or metastatic urothelial carcinoma (IMvigor211): a multicentre, open-label, phase 3 randomised controlled trial. Lancet. 2018;391(10122): 748-57.

20. Galsky MD, Arija JÁA, Bamias A, Davis ID, De Santis M, Kikuchi E, et al. Atezolizumab with or without chemotherapy in metastatic urothelial cancer (IMvigor130): a multicentre, randomised, placebo-controlled phase 3 trial. Lancet. 2020;395(10236):1547-57.

21. Tambaro R, Napoli MD, Pisano C, Cecere SC, Attademo L, Rossetti $S$, et al. From clinical trials to clinical use of checkpoint inhibitors for patients with metastatic urothelial cancer. Immunotherapy. 2021;13(1): 67-77.

22. Joshi M, Grivas P, Mortazavi A, Monk P, Clinton SK, Sue-Ann Woo M, et al. Alterations of DNA damage response genes correlate with response and overall survival in anti-PD-1/PD-L1-treated advanced urothelial cancer. Cancer Med. 2020;9(24):9365-72. 


\section{Sažetak}

\section{PRVA LINIJA LIJEČENJA METASTATSKOG UROTELNOG RAKA MOKRAĆNOG MJEHURA}

\section{Stamičar, M. Gamulin}

Ovaj rukopis daje pregled nedavnih saznanja o prvoj liniji terapije metastatskog urotelnog raka mokraćnog mjehura. Rak mokraćnog mjehura je na 10. mjestu u svijetu po učestalosti, a češći je u muškaraca. Bolesnike s metastatskim urotelnim rakom svrstava se u dvije skupine: prihvatljivi za liječenjem cisplatinom i nepodobni za liječenje cisplatinom. Bolesnici prihvatljivi za liječenje cisplatinom mogu se liječiti režimima temeljenim na cisplatini i imati bolji ishod. Bolesnici koji ne ispunjavaju uvjete za liječenje cisplatinom, njih oko $40-50 \%$, su oni s određenim komorbitetima i/ili lošim ECOG statusom te se mogu liječiti karboplatinom koja je, međutim, manje učinkovita. Nakon potvrde dijagnoze metastatskog urotelnog raka mokraćnog mjehura, potrebno je odabrati jedan od režima kemoterapije na bazi cisplatine. Međutim, treba imati na umu da cisplatina može uzrokovati nuspojave poput nefrotoksičnosti, neurotoksičnosti i ototoksičnosti. Danas u u prvoj liniji terapije važnu ulogu igraju inhibitori kontrolnih točaka (CPI), PD-1 i PD-L1. Smjernice NCCN-a uključuju avelumab, pembrolizumab i atezolizumab u sustavnu terapiju prve linije. Nedavno je studija "Javelin bladder 100" potvrdila pozitivan utjecaj avelumaba kao terapije održavanja u bolesnika koji ispunjavaju uvjete za liječenje cisplatinom i koji ne ispunjavaju uvjete za liječenje cisplatinom, zbog čega se kombinacija kemoterapije i avelumaba trenutno smatra najboljom terapijskom opcijom.

KLJUČNE RIJEČI: proa linija liječenja, metastatski urotelni rak mokraćnog mjehura, imunoterapija održavanja 